\title{
Quality characteristics and antioxidant activities of Muscat Bailey A wines mixed with different types of aronia
}

\author{
Kyu-Taek Choi $^{1}$, Sae-Byuk Lee ${ }^{1}$, Seong-Hyun Jeon ${ }^{1}$, Woo-Chang Lee ${ }^{1}$, \\ Jun-Su Choi ${ }^{1}$, Heui-Dong Park ${ }^{1,2 *}$ \\ ${ }^{1}$ School of Food Science and Biotechnology, Kyungpook National University, Daegu 40566, Korea \\ ${ }^{2}$ Institute of Fermentation Biotechnology, Kyungpook National University, Daegu 40566, Korea
}

\section{아로니아 첨가형태에 따른 Muscat Bailey A 와인의 품질 특성 및 항산화 활성}

\author{
최규택 ${ }^{1} \cdot$ 이새벽 $^{1} \cdot$ 전성현 $^{1} \cdot$ 이우창 $^{1} \cdot$ 최준수 $^{1} \cdot$ 박희동 $^{1,2 *}$ \\ ${ }^{1}$ 경북대학교 식품공학부, ${ }^{2}$ 경북대학교 발효생물공학연구소
}

\begin{abstract}
To improve the functionality and palatability of Muscat Bailey A (MBA) wine, MBA was fermented with three types of preprocessed aronia: Aronia fruit (AF), extract (AE), and powder (AP); aronia was chosen for its strong acerbity. The fermentation characteristics of the wines did not differ greatly, except that the $\mathrm{pH}$ of the AP wine was slightly higher than that of the other wines. The hue and intensity values of all the MBA wines with aronia were higher than those of the control, except for the hue value of the $\mathrm{AE}$ wine. In the Hunter's color value result, the $L^{*}$ value of the $\mathrm{AE}$ wine and the $a^{*}$ value of the control were the highest among all the wines; the $b^{*}$ values of all the MBA wines with aronia were higher than that of the control. The total phenolic compounds, total anthocyanin compound, total flavonoid content, DPPH free radical scavenging activity, ABTS radical scavenging activity, and FRAP of the AF and AP wines were considerably higher than those of the control, whereas those of the $\mathrm{AE}$ wine were slightly lower than those of the control. In a sensory evaluation, the AE wine obtained the highest color, sweetness, bittemess, sourness, body, and overall preference scores among all the wines, the whereas AF and AP wines obtained lower scores than the control for most criteria except color and body. This study suggests that different types of aronia can be used to improve the quality of Korean MBA wine.
\end{abstract}

Key words : Muscat Bailey A, Aronia melanocarpa, wine, fermentation, antioxidant activity

서 론

우리나라 와인산업은 1970년대 초, 곡물 유래 양조주를 대체하기 위한 정부의 과실주산업 육성 정책을 통하여 다수의 주류기업들이 각 지역에 포도단지 조성과 와인공 장을 설립하면서 국산와인의 생산이 시작되었다(Bang과 Cho, 2001). 국산 와인은 1969년 파라다이스의 '애플와인 파라다이스'를 시작으로 해태 '노블와인', 동양맥주 ‘마주
앙', 진로 ‘샤또 몽블르', 금복주 ‘두리앙', 대선주조 ‘그랑 주아', 파라다이스를 인수한 수석농산의 '위하여' 등이 생 산되면서 전성기를 맞이하였다(Ko, 2008; Jeong, 2014). 하 지만, 1987년 수입 자유화와 1988년 서울 올림픽을 계기로 수입 와인이 개방되면서 국내 대부분의 양조용 포도농장 이 점차 폐쇄되었고, 국산 와인은 종교행사용 미사주 형태 로만 소량 생산되었다(Lee 등, 2004). 그러나 1990년대 중 반 이후부터는 일부 소규모 와인업체가 등장하기 시작하

*Corresponding author. E-mail : hpark@knu.ac.kr, Phone :+82-53-950-5774, Fax :+82-53-950-6772

Received 27 November 2019; Revised 14 January 2020; Accepted 16 January 2020.

Copyright (C) The Korean Society of Food Preservation.

This is an Open Access article distributed under the terms of the Creative Commons Attribution Non-Commercial License (http://creativecommons.org/licenses/by-nc/4.0) which permits unrestricted non-commercial use, distribution, and reproduction in any medium, provided the original work is properly cited. 
였고, 2000년대 중반 무렵부터 정부가 전통주산업 육성 정책을 추진하면서 지역특산주인 과실주 시장이 확대되 었으며, 2010년 전후로 전북 무주, 경북 영천, 충북 영동지 역을 중심으로 농가형 소규모 와이너리가 다수 설립되며 지역별 와인 클러스터가 형성되었다(Hong과 Ko, 2015). 2015년 기준으로 국내 와인시장 규모는 약 2,500억 원 정도 이며, 그중 수입 포도주는 2000년부터 연평균 $7 \%$ 이상의 성장세를 보이며 약 1 억 8,400 만 달러로 국내 포도주 시장 의 $90 \%$ 이상을 차지하고 있다(Park 등, 2016).

와인의 품질은 원료 포도의 품종에 가장 큰 영향을 받으 며, 제조방법과 저장 용기에 따른 숙성방법 등에 따라 크게 영향을 받는다(Jeong, 2014; Yoon 등, 2017). 국내에서 재배 되는 대부분의 포도 품종은 양조품종이 아닌 Vitis labrusca 또는 Vitis vinifera와 Vitis labrusca를 hybrid한 품종들로써 이들은 당도가 낮고 산도가 강하며, 와인 제조시 일반적인 양조품종들에 비해 색상이나 아로마, 부케, 탄닌 함량 등이 낮은 것으로 알려져 있다(Lee와 Kim, 2006; Yook 등, 2007). 하지만, 그중에서 MBA(Muscat Bailey A) 포도 품종의 경 우에는 비교적 당도가 높고 색상이 진하여 국내 포도 품종 중 가장 우수한 양조 적성을 띄고 있는 것으로 알려져 있다(Hwang과 Park, 2010). 하지만 MBA 포도 품종 역시 유럽의 양조용 포도 품종과 경쟁하기 위해서 관능 및 품질 개선을 위한 노력이 요구되고 있다.

현재까지 보고된 국산 와인의 품질 개선을 위한 연구로 는 발효과정 시 첨가되는 당 종류 또는 감산 처리 방법에 따른 캠벨얼리(Campbell Early)와인의 품질 특성 비교(Kim 등, 2001; Lee와 Kim, 2006), 알코올 발효 최적화를 위한 상업용 양조 효모의 선별(Moon 등 2004; Roh 등, 2008), 국산 포도에서 분리된 야생효모와 토착효모의 발효 특성 비교(Kim 등, 2007; Choi 등, 2011; Kim 등, 2013) 및 말로락 틱 발효에 따른 MBA 와인의 품질향상 효과(Lee 등, 2015) 등 발효 공정 개선에 관한 연구가 주를 이루어 왔으며, 머루, 복분자, 블랙커런트 등을 첨가한 캠벨얼리 와인의 품질 개선 및 폴리페놀 성분 강화 연구(Yook 등, 2007), 아로니아를 혼합시킨 캠벨얼리 와인의 휘발성 향기성분, 색도, 생리활성 분석(Yoon 등, 2017), Pichia anomala와 Saccharomyces cerevisiae로 혼합발효한 캠벨얼리 와인과 아로니아 와인의 블렌딩에 따른 기능성 및 기호성 증진 효과(Jeong 등, 2017) 등 원료를 혼합하여 국산 와인의 경쟁 력을 강화시키는 연구들도 이루어져 왔다.

최근 몇 년간 슈퍼푸드로써 주목받고 있는 아로니아 (Aronia melanocarpa)는 장미과에 속하는 베리류의 열매로 써 2007년경 국내에 도입되어 2010년대 초반부터 재배 농가가 급증하였으며, 2017년 8,779톤이 생산되었다(Yoon 등, 2017). 아로니아의 anthocyanin 성분은 블루베리의 4 배, 크랜베리의 12 배, 딸기의 20 배, 포도의 80 배 정도 함유되어
있다고 알려져 있으며, 특히 시아닌 계열의 cyanidin3-O-galactoside와 cyanidin-3-O-arabinoside 등이 다량 포함 되어 이들에 의해 열매는 진한 적자색을 나타낸다(Han, 2013). 또한, epicatechin(EC), epigallocatechin(EGC) 등 탄 닌 및 카테킨류 성분이 녹차보다 10배 이상인 $15,000 \mathrm{mg} / \mathrm{kg}$ 이 함유되어 있다고 알려져 있다(Shin과 Choe, 2015). 이로 인해 아로니아는 항산화능이 베리류 중에서 가장 높은 것으로 알려져 있으며, 동맥경화, 심혈관질환, 암, 염증, 알러지성 피부질환, 주름개선 등에 효능이 있는 것으로 보고되어 있다(Hou, 2003; Jakobek 등, 2012). 하지만 아로 니아는 다양한 생리활성 물질을 함유하였음에도 불구하 고 신맛과 떫은맛이 너무 강해 생과로 이용되기 힘든 문제 점을 지니고 있다(Song, 2016). 따라서 최근에는 아로니아 의 강한 떫은맛을 상쇄시키면서 우수한 기능성을 살리기 위해 아로니아 분말, 아로니아 즙 등 다양한 형태로 식품에 첨가하는 연구가 이루어지고 있다(Park과 Chung, 2014; Lee 등, 2017; Kim 등, 2018).

본 연구에서는 국산 포도 품종 중 양조 적성이 가장 우수한 MBA 포도를 이용한 레드와인의 품질 향상을 위하 여, 아로니아가 함유한 다량의 생리활성 물질 및 진한 적색 소 성분을 통해 국산 $\mathrm{MBA}$ 포도 와인의 기능성 및 관능적 품질을 향상시키고자 하였다. 이를 위하여 아로니아를 생 과, 청, 분말 등 다양한 형태의 전처리 과정을 거친 후 MBA 포도와 함께 발효를 진행하였으며, 아로니아 첨가 형태에 따른 각 와인의 품질특성 및 생리활성 변화를 비교 분석하였다. 본 연구를 통해 국산 와인 고품질화 방안의 토대를 마련하는 동시에 과잉 생산되고 있는 국산 아로니 아의 활용 방안을 제시하여 국산 베리류 농산물의 가공 확대에 기여하고자 하였다.

\section{재료 및 방법}

\section{실험재료 및 균주}

와인 발효에 사용한 원료 포도는 2018년 10 월 경북 경산 지역에서 수확한 Muscat Bailey A(MBA) 품종을 사용하였 고, 아로니아는 2017년 9월 경북 칠곡 지역에서 수확한 Nero 품종(Aronia melanocarpa var Nero)을 냉장 또는 냉동 보관하면서 실험에 사용하였다. 실험에 사용한 균주는 상 업용 와인효모인 Saccharomyces cerevisiae Fermivin(DSM Food Specialties, Delft, Netherlands)을 사용하였다.

\section{아로니아 전처리}

아로니아 청은 생과와 백설탕(CJ Co., Seoul, Korea)을 1:0.8 비율로 혼합하여 $20^{\circ} \mathrm{C}$ 의 항온항습실에서 설탕을 완 전히 용해시킨 후, $10^{\circ} \mathrm{C}$ 숙성실에서 6개월간 침출 및 숙성 하여 $40 \mathrm{mesh}$ 체로 과육을 제거한 후, $4^{\circ} \mathrm{C}$ 의 저온실에 보관 
하면서 실험에 사용하였다. 아로니아 분말(aronia powder)은 생과를 진공동결건조(SFDTS-10K, Samwon Engineering, Busan, Korea)한 후, 분쇄기(FM-909T, Hanil Electric, Seoul, Korea)로 곱게 마쇄하여 실험에 사용하였다.

\section{와인의 제조}

와인의 제조를 위해 세척, 제경 및 파쇄된 $4.5 \mathrm{~kg}$ 의 MBA 포도 머스트에 형태별로 동량의 아로니아(생과 기준 500 $\mathrm{g}$ ), 즉 $500 \mathrm{~g}$ 의 파쇄된 아로니아 생과, $900 \mathrm{~g}$ 의 아로니아 청, $100 \mathrm{~g}$ 의 아로니아 분말을 각각 첨가한 후 발효에 이용하 였다. 발효 과정 중 폴리페놀 성분의 산화와 잡균 오염을 방지하기 위해 $150 \mathrm{ppm}$ 의 potassium metabisulfite(DAEJUNG CHEMICALS \& METALS CO., LTD, Siheung, Korea)를 첨 가하고, 최종 당도가 $23{ }^{\circ} \mathrm{Brix}$ 가 되도록 백설탕으로 보당하 였다. 아황산 처리 5 시간 후, 과즙 무게의 $0.02 \%(\mathrm{w} / \mathrm{w})$ 의 건조효모를 활성화시켜 접종하였다. 발효실 온도는 $20^{\circ} \mathrm{C}$ 로 설정하였고, 과피와 과육의 폴리페놀 성분의 추출을 용이하게 하기 위해 매일 2회 maceration을 실시하였으며, 이산화탄소의 발생이 현저히 줄고 알코올 함량이 최대치 에 도달하는 시점에서 발효를 종료하였다. 발효가 종료된 와인은 원심분리 $(4,973 \times \mathrm{g}, 10 \mathrm{~min})$ 하여 효모균체와 앙금 을 분리한 후, $4^{\circ} \mathrm{C}$ 에 보관하며 분석에 이용하였다.

\section{와인의 발효 특성 분석}

와인의 발효 특성과 이화학적 품질 특성 분석은 와인의 일부를 취하여 원심분리 $(4,973 \times \mathrm{g}, 10 \mathrm{~min})$ 한 후 얻은 상등 액을 이용하였다. pH는 pH meter(Mettler-Toledo MP225K, Schwerzenbach, Switzerland)를 이용하여 측정하였고, 총산 은 $\mathrm{AOAC}$ 표준시험법으로 측정하였다(AOAC, 2000). 알코 올 함량은 $15^{\circ} \mathrm{C}$ 에서 시료 $100 \mathrm{~mL}$ 를 취하여 증류한 증류액 을 주정계를 이용하여 측정하였으며, 가용성 고형분( $\left.{ }^{\circ} \mathrm{Brix}\right)$ 은 굴절당도계(ATAGO, Co, N-1a, Kyoto, Japan)를 이용하 여 측정하였다. 환원당 함량은 $\mathrm{DNS}(3,5$-dinitrosalicylic acid, Sigma Chemical Co., St. Louis, MO, USA) 시약을 사용하여 비색 정량법에 따라 측정하였다(Ahmed, 2004). 시료 $0.3 \mathrm{~mL}$ 에 $\mathrm{DNS}$ 시약 $1 \mathrm{~mL}$ 를 첨가하여 $95^{\circ} \mathrm{C}$ 에서 5 분간 반응 후, 증류수 $7 \mathrm{~mL}$ 를 첨가하여 분광광도계(Shimazdu Co. UV-1601, Kyoto, Japan)를 이용하여 $550 \mathrm{~nm}$ 에서 흡광 도를 측정하고 glucose 표준곡선으로부터 환원당 함량을 환산하였다. 생균수는 원심분리하지 않은 시료를 단계 희 석하여 YPD 고체배지에 도말하여 $30^{\circ} \mathrm{C}$ 에서 48 시간 배양 한 후 형성된 군집을 계수하였다(Ministry of Food and Drug Safety, 2010).

\section{색도 분석}

와인의 hue와 intensity 분석은 분광광도계(Shimazdu Co.
UV-1601, Kyoto, Japan)를 이용하여 각각 $420 \mathrm{~nm}, 520 \mathrm{~nm}$ 에 서 흡광도를 측정하였다. Hue 값은 $420 \mathrm{~nm}$ 와 $520 \mathrm{~nm}$ 의 흡광도 비율 $(420 / 520 \mathrm{~nm})$ 로 나타내었으며, intensity 값은 $420 \mathrm{~nm}$ 와 $520 \mathrm{~nm}$ 의 흡광도 합 $(420+520 \mathrm{~nm})$ 으로 나타내었 다(Ortiz 등, 2013). Hunter's color value는 colorimeter(CM3600d, Konica Minolta, Osaka, Japan)를 이용하여 L* (lightness), a*(redness), b*(yellowness)값으로 나타내었다.

\section{항산화 성분 및 항산화 활성 측정}

와인의 항산화 성분은 총 페놀성 화합물(total phenolic content), 총 플라보노이드 화합물(total flavonoid contents), 총 안토시아닌 화합물(total anthocyanin content) 함량을 측 정하였다. 총 페놀성 화합물의 함량은 Folin-Denis법에 따 라 비색 정량하였다(Amerine과 Ough, 1980). 시료 $2 \mathrm{~mL}$ 에 $50 \%$ phenol reagent(Folin-Ciocalteu phenol reagent)(Junsei Chemical Co., Ltd., Tokyo, Japan), $2 \mathrm{~mL}$ 를 가하고, 3 분 동안 실온에 방치한 후 $10 \% \mathrm{Na}_{2} \mathrm{CO}_{3}$ (DUKSAN, Ansan, Korea) $2 \mathrm{~mL}$ 를 첨가하여 1 시간 동안 실온의 암실에서 반응 시킨 후, 분광광도계로 $700 \mathrm{~nm}$ 에서 흡광도를 측정하였으 며, tannic acid(DAEJUNG CHEMICALS \& METALS CO., LTD, Siheung, Korea)표준곡선으로 총 페놀성 화합물 함량 을 환산하였다. 총 플라보노이드 화합물의 함량은 Zhishen 등(1999)의 방법을 변형하여 정량하였다. 즉, $70 \mu \mathrm{L}$ 의 시료 에 $430 \mu \mathrm{L}$ 의 $50 \%$ ethanol(Ethyl alcohol, absolute, DUKSAN, Ansan, Korea)과 $50 \mu \mathrm{L}$ 의 $5 \% \mathrm{NaNO}_{2}(\mathrm{DUKSAN}$, Ansan, Korea)를 첨가하여 30 분 동안 실온에 방치한 후, $50 \mu \mathrm{L}$ 의 $10 \% \mathrm{Al}\left(\mathrm{NO}_{3}\right)_{3} \cdot 9 \mathrm{H}_{2} \mathrm{O}($ Sigma Chemical Co., St. Louis, MO, $\mathrm{USA}$ )를 가하고 실온에서 6 분 동안 반응시켰다. 이후 500 $\mu \mathrm{L}$ 의 $1 \mathrm{~N} \mathrm{NaOH}(\mathrm{DUKSAN}$, Ansan, Korea)를 가하고 분광광 도계로 $510 \mathrm{~nm}$ 에서 흡광도를 측정하였으며, catechin (Sigma Chemical Co., St. Louis, MO, USA) 표준곡선으로 총 플라보노이드 화합물 함량을 환산하여 나타내었다. 총 안토시아닌 화합물의 함량은 Lee 등(2005)의 방법을 변형 하여 정량하였다. 즉, $0.025 \mathrm{M}$ potassium chloride buffer (DUKSAN, Ansan, Korea)( $\mathrm{pH}$ 1.0)와 0.4 M sodium acetate buffer(Sodium acetate trihydrate, DAEJUNG CHEMICALS \& METALS CO., LTD, Siheung, Korea)(pH 4.5)에 시료를 적정량 희석한 다음, 실온의 암실에서 30 분 동안 반응시켰 다. 이후 반응액을 분광광도계로 $520 \mathrm{~nm}$ 와 $700 \mathrm{~nm}$ 에서 흡광도를 측정한 후, cyanidin-3-glucoside의 몰 흡광계수 $(\varepsilon$ $\left.=26,900 \mathrm{M}^{-1} \mathrm{~cm}^{-1}\right)$ 를 이용하여 총 안토시아닌 화합물 함 량을 환산하여 나타내었다.

와인의 항산화능 분석은 2,2-diphenyl-1-picryl-hydrazyl (DPPH) radical 소거능, 2,2'-azino-bis(3-ethylbenzothiazoline -6-sulphonic acid)(ABTS) radical 소거능, ferric ion reducing antioxidant power(FRAP) 활성을 측정하였다. DPPH radical 
소거능 분석은 96-well plate에 순차적으로 희석된 시료 $1 \mu \mathrm{L}$ 를 넣은 후, $199 \mu \mathrm{L}$ 의 $0.1 \mathrm{mM}$ DPPH working solution(2 2-Diphenyl-1-picrylhydrazyl, Sigma Chemical Co., St. Louis, $\mathrm{MO}, \mathrm{USA})$ 을 첨가한 다음, 실온의 암실에서 10 분간 반응시 킨 후, multi label counter(Victor3, Perkin Elmer, MA, USA) 로 $517 \mathrm{~nm}$ 에서 흡광도를 측정하였다. 표준물질로는 ascorbic acid(DAEJUNG CHEMICALS \& METALS CO., LTD, Siheung, Korea)를 사용하였으며, control은 ethanol을 사용하여 측정하였다(Blois, 1958). ABTS radical 소거능 분석은 96 well plate에 순차적으로 희석된 시료 $20 \mu \mathrm{L}$ 를 넣은 후, $180 \mu \mathrm{L}$ 의 $\mathrm{ABTS}$ solution(ABTS ${ }^{\mathrm{TM}}$, Sigma Chemical Co., St. Louis, MO, USA)을 첨가한 다음, 실온의 암실에서 7분간 반응시킨 후, multi label counter로 $734 \mathrm{~nm}$ 에서 흡광도 를 측정하였다. 표준물질로는 $\operatorname{trolox}(( \pm)-6$-hydroxy-2,5,7,8tetramethylchromane-2-carboxylic acid, Sigma Chemical Co., St. Louis, MO, USA)를 사용하였으며, control은 증류수를 사용하여 측정하였다(Stratil 등, 2008). FRAP 활성은 Benzie와 Strain(1996)의 방법을 변형하여 측정하였다. 96 well plate에 순차적으로 희석된 시료 $25 \mu \mathrm{L}$ 를 넣은 후, $300 \mathrm{mM}$ acetate buffer(Sodium acetate trihydrate, DAEJUNG CHEMICALS \& METALS CO., LTD, Siheung, Korea)(pH 3.6), $10 \mathrm{mM}$ 2,4,6-tripyridyl-S-triazine(Sigma Chemical Co., St. Louis, MO, USA)과 $20 \mathrm{mM}$ ferric chloride(Sigma Chemical Co., St. Louis, MO, USA)를 10:1:1(v/v/v) 비율로 제조한 $175 \mu \mathrm{L}$ 의 cocktail solution을 첨가한 다음, 실온의 암실에서 30 분간 반응시킨 후, multi label counter로 590 $\mathrm{nm}$ 에서 흡광도를 측정하였다. 표준물질은 trolox를 사용하 였으며, trolox equivalent $\mathrm{mM}(\mathrm{TE} \mathrm{mM})$ 로 나타내었다.

\section{관능검사}

와인의 관능검사는 관능평가 경험이 있는 대학원생 20 명을 대상으로 실험 방법과 목적을 설명한 후, 무작위로 제시된 시료에 대하여 색, 향, 단맛, 쓴맛, 신맛, 조직감 및 전반적인 기호도에 대하여 평가하였다. 7점 척도법으로 평가하였으며, 7점은 매우 좋다, 1점은 매우 나쁘다로 평가 하였다. 본 연구의 관능평가는 경북대학교 생명윤리심의
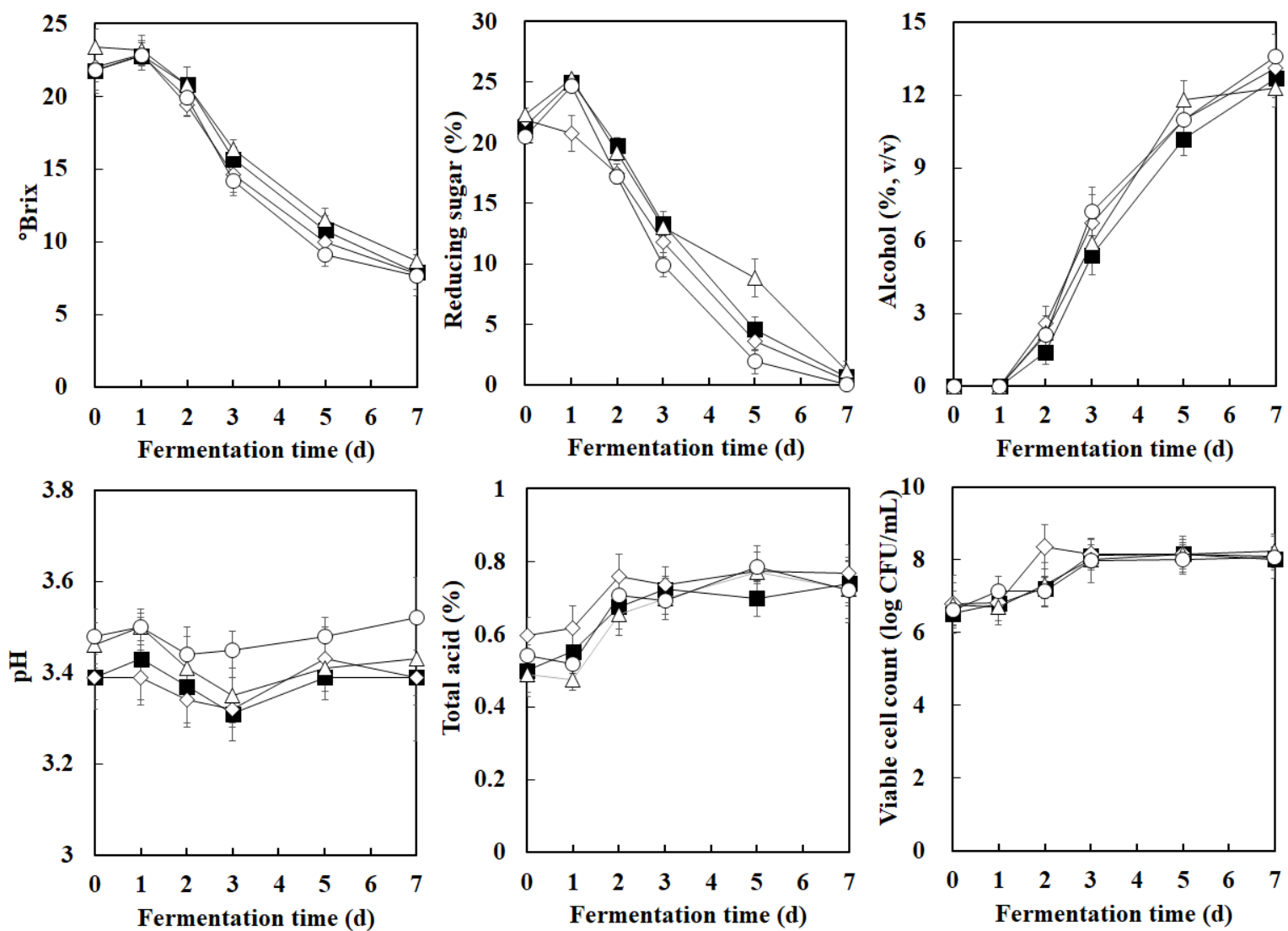

Fig. 1. Changes in the soluble solid, reducing sugar, alcohol, pH, total acidity, and viable cell count of MBA wines added with different types of preprocessed aronia during alcohol fermentation.

$\mathbf{\square}, \mathrm{MBA} ; \diamond, \mathrm{MBA}+$ aronia fruit; $\triangle$, MBA + aronia extract; $\bigcirc, \mathrm{MBA}+$ aronia powder. 
위원회의 규정에 따라 심의하여 승인번호(2019-0010)를 받아 진행하였다.

\section{통계처리}

모든 실험 결과는 3회 반복 실시하여 실험 결과를 평균 표준편차로 나타내었고, 실험군 간의 유의성을 검정하기 위하여 SAS 통계처리(Statstical Analysis System, SAS Insititute Inc., Cary, USA)를 이용한 분산분석(ANOVA)과 Duncan의 다중범위검증(Duncan's multiple range test, $\mathrm{p}<0.05$ )으로 유의성을 검증하였다.

\section{결과 및 고찰}

\section{아로니아 첨가 형태에 따른 $\mathrm{MBA}$ 와인의 발효 특성}

아로니아 첨가 형태에 따른 $\mathrm{MBA}$ 와인의 발효 특성을 조사하기 위하여, 발효 과정 중 당도, 환원당, 알코올, $\mathrm{pH}$, 총산도, 생균수의 변화를 관찰한 결과를 Fig. 1 에 나타내었 다. MBA 포도와 아로니아의 생과의 당도는 $18.3^{\circ} \mathrm{Brix}$ 와 $11.3{ }^{\circ} \mathrm{Brix}$ 였으며, 아로니아 첨가 형태에 따라 일부 상이한 초기 당도는 백설탕으로 보당하여 $23{ }^{\circ} \mathrm{Brix}$ 로 알코올 발효 를 진행하였다. 발효의 진행 속도는 아로니아 분말, 아로니 아 생과, 아로니아 무첨가, 아로니아 청의 순으로 빨랐으 며, 각 와인의 최종 당도는 아로니아 청 첨가 와인이 8.7 ${ }^{\circ} \mathrm{Brix}$ 로 가장 높았고, 나머지 와인들은 7.7-7.9 ${ }^{\circ} \mathrm{Brix}$ 로 나타났다. 환원당 분석에서도 아로니아 청 첨가 와인을 제외한 모든 시험구에서 $1 \%$ 미만으로 측정되어 대부분의 환원당을 소비한 것으로 판단되었다. 알코올 함량 분석 결과, 발효 2 일차부터 당 소모와 비례하여 5 일차까지 급격 하게 증가하였으며, 발효 7일차까지 완만하게 발효가 진행 되었다. 최종 알코올의 농도는 아로니아 분말(13.6\%), 아
로니아 생과(13.1\%), 아로니아 무첨가(12.7\%), 아로니아 청 $(12.3 \%)$ 순으로 나타났으며, 이는 최종 와인의 잔당 함량 과 일치한 결과를 나타내었다. 와인에서 $\mathrm{pH}$ 는 효모의 발효 에 영향을 미치며, 발효 이후 품질 보존에도 큰 영향을 끼치는 중요한 요소이다(Park 등, 2002). 일반적으로 와인 의 $\mathrm{pH}$ 는 3.2-3.6 정도가 가장 바람직하다고 알려져 있으 며, $\mathrm{pH}$ 가 3.2 이하일 때는 신맛이 강해지고, $\mathrm{pH} 3.0$ 이하에 서는 발효가 저해된다고 알려져 있으며, $\mathrm{pH}$ 가 3.6 이상이 되면 잡균에 오염될 가능성이 높아진다고 보고되어 있다 (Park 등, 2002; Jeong 등, 2017). 본 연구에서는 아로니아 분말 첨가 와인의 $\mathrm{pH}$ 가 3.52 로 다른 $\mathrm{MBA}$ 와인들보다 약간 높게 측정되었으나 모든 $\mathrm{MBA}$ 와인들이 적정 $\mathrm{pH}$ 범위 안에 드는 것을 확인하였다. 또한, 발효 초기 아로니아 생과 첨가구의 총산 함량 $(0.597 \%)$ 은 아로니아 무첨가구 $(0.499 \%)$ 보다 상대적으로 높게 나타났으며, 발효 종료 후 에도 아로니아 생과 첨가구에서 가장 높은 총산 함량 $(0.766 \%)$ 이 검출되었다. Jeong 등(2017)과 Yoon 등(2017) 의 연구에서도 아로니아 와인의 총산 함량이 발효 초기 및 발효 종료 후에 캠벨얼리 와인보다 높다고 보고되어 있다. 발효 과정 중 생균수의 변화는 아로니아 첨가 유무와 상관없이 발효 초기에 일정하게 증가하다가 발효 2일차부 터 발효 종료시까지 $7 \log \mathrm{CFU} / \mathrm{mL}$ 이상의 높은 생육도 값을 나타내며 정상적으로 발효가 진행되었다. 전반적으 로 아로니아 첨가 와인들의 발효 특성을 살펴보았을 때, 모든 시험구에서 $12 \%$ 이상의 높은 알코올이 생성되었음 을 확인하였고, 아로니아 첨가 형태에 따른 효모의 생육 억제나 이상 발효 등의 현상은 일어나지 않은 것으로 확인 되었다. 따라서 $\mathrm{MBA}$ 와인 제조시에 총 와인 무게 대비 $10 \%$ 이내의 아로니아는 어떠한 형태로 첨가되더라도 와 인의 $\mathrm{pH}$ 등에 큰 영향을 주지 않아, 효모의 생육 및 와인

Table 1. Hue and intensity values of MBA wines added with different types of the preprocessed aronia during alcohol fermentation

\begin{tabular}{|c|c|c|c|c|c|c|c|c|c|}
\hline & & Day 0 & Day 1 & Day 2 & Day 3 & Day 4 & Day 5 & Day 6 & Day 7 \\
\hline & rol & $\left..023 \pm 0.007^{2 \mathrm{a} a 3}\right)$ & $0.914 \pm 0.004^{\mathrm{b}}$ & $0.937 \pm 0.011^{\mathrm{a}}$ & $0.786 \pm 0.005^{\mathrm{b}}$ & $0.739 \pm 0.006^{\mathrm{b}}$ & $0.583 \pm 0.015^{\mathrm{c}}$ & $0.578 \pm 0.014^{\mathrm{c}}$ & $0.603 \pm 0.012^{\mathrm{c}}$ \\
\hline & A & $0.613 \pm 0.005^{\mathrm{c}}$ & $930 \pm 0.026^{\mathrm{b}}$ & $0.956 \pm 0.035^{\mathrm{a}}$ & $0.846 \pm 0.013^{\mathrm{a}}$ & $0.834 \pm 0.015^{\mathrm{a}}$ & $0.679 \pm 0.004^{\mathrm{a}}$ & $0.692 \pm 0.017^{\mathrm{a}}$ & $0.670 \pm 0.013^{\mathrm{b}}$ \\
\hline & B & $0.876 \pm 0.022^{\mathrm{b}}$ & $1.004 \pm 0.003^{\mathrm{a}}$ & $0.938 \pm 0.029^{\mathrm{ab}}$ & $0.757 \pm 0.013^{\mathrm{c}}$ & $0.730 \pm 0.010^{\mathrm{b}}$ & $0.623 \pm 0.005^{\mathrm{b}}$ & $0.630 \pm 0.007^{\mathrm{b}}$ & $0.674 \pm 0.008^{\mathrm{b}}$ \\
\hline & $\mathrm{C}$ & $608 \pm 0.007^{\mathrm{c}}$ & $.010^{\mathrm{b}}$ & $0.903=$ & 0.735 & $0.685 \pm 0.014^{\mathrm{c}}$ & $0.678 \pm 0.017^{\mathrm{a}}$ & $0.652 \pm 0.010^{\mathrm{b}}$ & $0.711 \pm 0.016^{\mathrm{a}}$ \\
\hline \multirow{4}{*}{ Intensity } & Control & $1.192 \pm 0.009^{\mathrm{d}}$ & $3.648 \pm 0.015^{\mathrm{d}}$ & $4.138 \pm 0.025^{\mathrm{c}}$ & $4.450 \pm 0.016^{\mathrm{b}}$ & $3.948 \pm 0.011^{\mathrm{c}}$ & $3.537 \pm 0.014^{\mathrm{c}}$ & $3.325 \pm 0.048^{\mathrm{b}}$ & $2.842 \pm 0.044^{\mathrm{c}}$ \\
\hline & A & $5.273 \pm 0.094^{\mathrm{a}}$ & $5.950 \pm 0.042^{\mathrm{a}}$ & $6.580 \pm 0.041^{\mathrm{a}}$ & $6.540 \pm 0.013^{\mathrm{a}}$ & $5.602 \pm 0.038^{\mathrm{a}}$ & $5.268 \pm 0.051^{\mathrm{a}}$ & $4.983 \pm 0.068^{\mathrm{a}}$ & $4.725 \pm 0.050^{\mathrm{a}}$ \\
\hline & B & $2.171 \pm 0.006^{\mathrm{c}}$ & $3.756 \pm 0.012^{\mathrm{c}}$ & $3.870 \pm 0.030^{\mathrm{d}}$ & $3.704 \pm 0.027^{\mathrm{d}}$ & $3.386 \pm 0.008^{\mathrm{d}}$ & $2.904 \pm 0.036^{\mathrm{d}}$ & $2.631 \pm 0.036^{\mathrm{c}}$ & $2.411 \pm 0.015^{\mathrm{d}}$ \\
\hline & $\mathrm{C}$ & $3.593 \pm 0.035^{\mathrm{b}}$ & $4.605 \pm 0.027^{b}$ & $4.684 \pm 0.036^{\mathrm{b}}$ & $4.387 \pm 0.030^{\mathrm{c}}$ & $4.271 \pm 0.026^{\mathrm{b}}$ & $3.848 \pm 0.011^{\mathrm{b}}$ & $3.294 \pm 0.065^{\mathrm{b}}$ & $2.991 \pm 0.013^{b}$ \\
\hline
\end{tabular}

${ }^{1)}$ Control, Muscat Bailey A (MBA); A, MBA+aronia fruit; b, MBA+aronia extract; C, MBA+aronia powder.

${ }^{2)}$ The values were expressed as mean $\pm \mathrm{SD}(\mathrm{n}=3)$.

${ }^{3)}$ Different letters within the same column indicate significant different $(\mathrm{p}<0.05)$. 
발효에 영향을 주지 않는 것으로 판단되었다.

\section{색도 분석}

레드 와인의 색도는 와인 품질의 주요 판단 기준으로 적자색을 나타내는 anthocyanin계 색소와 황녹색을 나타내 는 chlorophyll, carotene, xanthophyll, flavone 등에 영향을 받는다(Kim 등, 2010). 와인의 발효 과정 중 색도와 갈변도 의 변화 등을 알아보기 위해 주로 이용되는 hue value와 intensity value를 측정한 결과를 Table 1 에 나타내었다. Hue value에서 대조구는 발효초기에 가장 높은 값을 나타내며 서서히 감소하였으나, 아로니아 첨가 발효 시험구들은 발효 $1-2$ 일 차까지 증가하다가 감소하는 경향을 나타내었다. 일반적으로 정상적인 레드 와인의 hue value는 0.5 내외로 나타나며, 산화가 진행된 경우 1.0 이상이 나타난다고 알려 져 있다(Hwang과 Park, 2010). 아로니아를 첨가한 와인의 경우, hue value는 $0.670-0.711$ 의 범위를 나타내었으며 아 로니아를 첨가하지 않은 대조구(0.603)보다 높은 값을 나타 내었다. 본 연구에서는 모든 시험구의 최종 와인은 hue value 가 1.0 이하로 측정되어 정상적 와인의 범위에 포함된다고 판단되었다. 발효기간 중 intensity value의 변화는 발효 초기 에 아로니아 첨가 발효 시험구들의 intensity value가 아로니 아를 첨가하지 않은 대조구보다 높게 나타났으며, 발효 23 일차까지 증가하다가 서서히 감소하는 것으로 나타났다. 최종 와인의 intensity value는 각 시험구별로 유의적인 차이 를 보였으며, 아로니아 생과 첨가 발효 시험구(4.725)가 가
장 높은 intensity value를 나타내었고, 아로니아 분말 시험구 (2.991), 대조구(2.842), 아로니아 청 시험구(2.411) 순으로 intensity value를 나타내었다. Intensity value는 색의 강도와 상관관계를 나타내며, 육안 관찰에서 진한 색을 띄는 와인 의 intensity value가 높게 나타나는 것으로 확인되었다. 아로 니아 과육이 첨가되지 않은 아로니아 청 시험구는 대조구보 다 intensity value가 낮게 나타났다.

각 와인의 발효 과정 중 Hunter's color value의 변화 관찰 결과를 Table 2에 나타내었다. L* value(투명도)는 대부분 의 시험구에서 발효 초기 크게 감소하였다가 알코올 함량 이 높아진 발효 중기 이후부터 종료 시점까지 서서히 상승 하는 경향을 나타내었다. a* value(적색도) 분석 결과, 대조 구와 아로니아 청 시험구는 발효 초기 가장 낮은 $a^{*}$ value를 나타내다가 발효가 진행되면서 서서히 증가하는 경향을 나타내었으나, 아로니아 생과와 분말 시험구에서는 발효 초기 $a^{*}$ value가 서서히 감소하다가 발효 2-3일 째부터 서서히 증가하는 경향을 나타내었다. 최종 와인의 $\mathrm{a}^{*}$ value 는 대조구(31.41)가 가장 높게 나타났으며, 아로니아 청 (30.80), 아로니아 분말(30.47), 아로니아 생과(23.82) 순으 로 측정되었다. 이는 $\mathrm{L}^{*}$ value가 가장 낮은 아로니아 생과 시험구가 a* value도 가장 낮게 나타난 것으로 설명될 수 있으며, 아로니아 혼합비율이 증가할수록 $\mathrm{L}^{*}$ value와 a* value가 감소하는 경향을 나타내었다는 Yoon 등(2017)의 연구 결과와 일치하였다. $b^{*}$ value(황색도)는 발효 초기 아로니아 첨가 시험구들이 대조구보다 유의적으로 높게

Table 2. Hunter's color values of MBA wines added with different types of the preprocessed aronia during alcohol fermentation

\begin{tabular}{|c|c|c|c|c|c|c|c|c|c|}
\hline & & Day 0 & Day 1 & Day 2 & Day 3 & Day 4 & Day 5 & Day 6 & Day 7 \\
\hline \multirow{4}{*}{$\mathrm{L}^{*}$} & Control & $49.81 \pm 0.18^{2) \mathrm{a} 33}$ & $25.31 \pm 0.10^{\mathrm{b}}$ & $25.25 \pm 0.04^{\mathrm{a}}$ & $25.26 \pm 0.09^{b}$ & $25.86 \pm 0.09^{\mathrm{b}}$ & $26.60 \pm 0.05^{\mathrm{b}}$ & $27.05 \pm 0.03^{\mathrm{b}}$ & $28.89 \pm 0.11^{\mathrm{b}}$ \\
\hline & A & $22.13 \pm 0.10^{\mathrm{d}}$ & $20.61 \pm 0.05^{\mathrm{d}}$ & $21.12 \pm 0.04^{\mathrm{c}}$ & $21.71 \pm 0.03^{\mathrm{d}}$ & $21.09 \pm 0.07^{\mathrm{d}}$ & $21.63 \pm 0.04^{\mathrm{d}}$ & $22.17 \pm 0.02^{\mathrm{d}}$ & $22.89 \pm 0.03^{\mathrm{d}}$ \\
\hline & B & $40.95 \pm 0.04^{\mathrm{b}}$ & $25.89 \pm 0.01^{\mathrm{a}}$ & $25.66 \pm 0.35^{\mathrm{a}}$ & $25.87 \pm 0.03^{\mathrm{a}}$ & $26.74 \pm 0.17^{\mathrm{a}}$ & $28.27 \pm 0.06^{\mathrm{a}}$ & $29.46 \pm 0.01^{\mathrm{a}}$ & $30.70 \pm 0.02^{\mathrm{a}}$ \\
\hline & $\mathrm{C}$ & $30.56 \pm 0.11^{\mathrm{c}}$ & $24.93 \pm 0.03^{\mathrm{c}}$ & $24.63 \pm 0.03^{\mathrm{b}}$ & $24.38 \pm 0.04^{\mathrm{c}}$ & $24.62 \pm 0.04^{\mathrm{c}}$ & $25.96 \pm 0.03^{\mathrm{c}}$ & $26.84 \pm 0.01^{\mathrm{c}}$ & $28.02 \pm 0.04^{\mathrm{c}}$ \\
\hline \multirow{4}{*}{$\mathrm{a}^{*}$} & Control & $14.12 \pm 0.17^{\mathrm{d}}$ & $25.54 \pm 0.14^{\mathrm{a}}$ & $24.26 \pm 0.07^{b}$ & $25.99 \pm 0.09^{b}$ & $29.05 \pm 0.09^{b}$ & $30.44 \pm 0.03^{\mathrm{b}}$ & $30.53 \pm 0.02^{\mathrm{b}}$ & $31.41 \pm 0.09^{\mathrm{a}}$ \\
\hline & A & $18.29 \pm 0.23^{\mathrm{c}}$ & $12.90 \pm 0.02^{\mathrm{d}}$ & $15.47 \pm 0.03^{\mathrm{d}}$ & $19.12 \pm 0.06^{\mathrm{d}}$ & $4^{\mathrm{d}}$ & $20.30 \pm 0.07^{\mathrm{d}}$ & $=0.02^{\mathrm{d}}$ & $0.13^{\mathrm{d}}$ \\
\hline & B & $20.83 \pm 0.26^{\mathrm{b}}$ & $25.41 \pm 0.07^{\mathrm{b}}$ & $25.19 \pm 0.10^{\mathrm{a}}$ & $27.40 \pm 0.01^{\mathrm{a}}$ & $29.50 \pm 0.16^{\mathrm{a}}$ & $31.03 \pm 0.14^{\mathrm{a}}$ & $31.49 \pm 0.03^{\mathrm{a}}$ & $30.80 \pm 0.05^{\mathrm{b}}$ \\
\hline & $\mathrm{C}$ & $32.83 \pm 0.22^{\mathrm{a}}$ & $24.49 \pm 0.06^{\mathrm{c}}$ & $23.69 \pm 0.03^{\mathrm{c}}$ & $25.73 \pm 0.04^{\mathrm{c}}$ & $27.38 \pm 0.05^{\mathrm{c}}$ & $29.48 \pm 0.06^{\mathrm{c}}$ & $30.80 \pm 0.01^{\mathrm{c}}$ & $30.47 \pm 0.03^{\mathrm{c}}$ \\
\hline \multirow{4}{*}{$\mathrm{b}^{*}$} & Control & $0.82 \pm 0.09^{\mathrm{d}}$ & $6.17 \pm 0.02^{\mathrm{c}}$ & $7.45 \pm 0.02^{\mathrm{b}}$ & $8.93 \pm 0.05^{\mathrm{a}}$ & $6.75 \pm 0.09^{b}$ & $5.84 \pm 0.02^{\mathrm{d}}$ & $5.39 \pm 0.01^{\mathrm{d}}$ & $4.53 \pm 0.13^{\mathrm{d}}$ \\
\hline & A & $5.37 \pm 0.10^{\mathrm{b}}$ & $3.16 \pm 0.02^{\mathrm{d}}$ & $4.39 \pm 0.01^{\mathrm{d}}$ & $6.33 \pm 0.02^{\mathrm{d}}$ & $5.83 \pm 0.02^{\mathrm{c}}$ & $6.26 \pm 0.01^{\mathrm{b}}$ & $7.07 \pm 0.02^{\mathrm{a}}$ & $7.41 \pm 0.09^{\mathrm{a}}$ \\
\hline & B & $3.85 \pm 0.10^{\mathrm{c}}$ & $6.75 \pm 0.01^{\mathrm{b}}$ & $8.11 \pm 0.03^{\mathrm{a}}$ & $8.38 \pm 0.02^{\mathrm{b}}$ & $6.72 \pm 0.15^{\mathrm{b}}$ & $5.89 \pm 0.02^{\mathrm{c}}$ & $5.48 \pm 0.02^{\mathrm{c}}$ & $5.47 \pm 0.02^{\mathrm{c}}$ \\
\hline & $\mathrm{C}$ & $9.36 \pm 0.08^{\mathrm{a}}$ & $7.61 \pm 0.02^{\mathrm{a}}$ & $7.08 \pm 0.02^{\mathrm{c}}$ & $7.72 \pm 0.03^{\mathrm{c}}$ & $7.05 \pm 0.02^{\mathrm{a}}$ & $6.42 \pm 0.01^{\mathrm{a}}$ & $6.15 \pm 0.01^{\mathrm{b}}$ & $6.60 \pm 0.02^{\mathrm{b}}$ \\
\hline
\end{tabular}

${ }^{1)}$ Control, Muscat Bailey A (MBA); A, MBA+aronia fruit; B, MBA+aronia extract; C, MBA+aronia powder.

${ }^{2)}$ The values were expressed as mean \pm SD $(n=3)$.

${ }^{3}$ Different letters within the same column indicate significant different $(p<0.05)$. 
측정되었으나, 발효가 진행되면서 유사한 값을 나타내다 가 최종 와인에서는 아로니아 첨가 시험구들의 $b^{*}$ value가 대조구보다 높게 측정되었다. 이는 아로니아 혼합시 캠벨 얼리 와인의 b* value가 증가하였다는 Jeong 등(2017)과 Yoon 등(2017)의 연구 결과들과 일치하였다.

와인의 색도는 와인 품질 평가의 주요 척도이며, 발효와 숙성 중 색도 변화의 관찰은 이상 발효와 숙성을 예측하는
지표로도 활용된다. 와인의 발효 중 색 변화는 발효 초기 불투명한 붉은 빛을 띄다가 알코올이 생성된 이후 $\mathrm{L}^{*}$ value 가 증가하면서 짙은 붉은색으로 바뀌기 시작한다. 본 연구 에서도 발효가 진행되면서 포도와 아로니아의 색소가 침 출되면서 발효 종료시까지 $\mathrm{a}^{*}$ value가 서서히 짙어지는 것으로 나타났다. 아로니아 첨가에 따른 변화는 hue value 와 $\mathrm{b}^{*}$ value가 대조구보다 증가하였으며, 아로니아 생과
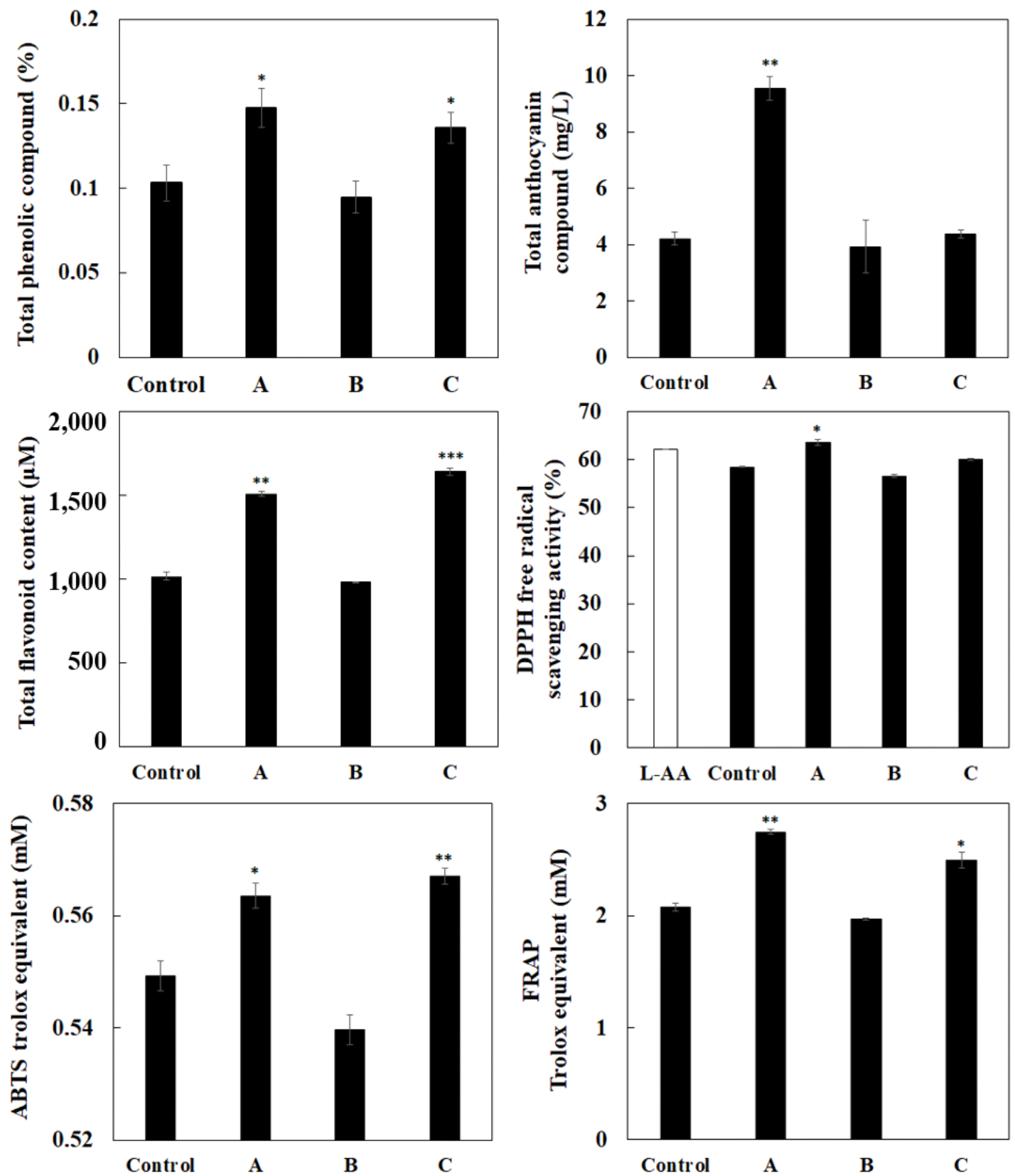

Fig. 2. Total phenolic compound, total anthocyanin compound, total flavonoid content, DPPH free radical scavenging activity, ABTS radical scavenging activity, and ferric ion reducing antioxidant power of MBA wines added with different types of preprocessed aronia. Control, MBA; A, MBA + aronia fruit; B, MBA + aronia extract; C, MBA + aronia powder; L-AA, 100 ppm of L-ascorbic acid. 
첨가구는 육안 관찰에서 가장 짙은 색을 나타내며, intensity value가 가장 높게 측정되었다. 반면, 아로니아 생과 첨가구의 $\mathrm{L}^{*}$ value, $\mathrm{a}^{*}$ value는 가장 낮게 측정되었으 며, 이는 아로니아의 짙은 색소 성분과 적포도 색소 성분의 차이에 기인하는 것으로 판단되었으며, 색도 차이에 따른 색소 성분의 차이는 생리활성물질 및 항산화 활성도 변화 에 영향을 미칠 것으로 판단된다(Stintzing 등, 2002).

\section{항산화 성분 및 항산화 활성 비교}

과실류에 다량 함유된 폴리페놀 화합물은 항산화능에 중요한 인자이며, 특히 적포도에 함유된 붉은 빛깔의 안토 시아닌계 색소는 레드와인의 항산화능에 큰 영향을 미친 다. 본 연구에서는 $\mathrm{MBA}$ 와인의 기능성을 향상시키기 위하 여 아로니아를 첨가하고자 하였으며, 다양한 전처리 방법 에 따른 최종 $\mathrm{MBA}$ 와인의 항산화 성분 및 항산화 활성에 미치는 영향을 조사하기 위하여 각 와인의 총 페놀성 화합 물, 총 안토시아닌, 총 플라보노이드, DPPH 라디칼 소거능, $\mathrm{ABTS}$ 라디칼 소거능, FRAP 활성을 측정한 결과를 Fig. 2에 나타내었다.

총 페놀성 화합물 분석 결과, 아로니아 생과와 아로니아 분말을 첨가한 $\mathrm{MBA}$ 와인의 경우, 각각 $0.148 \%$ 와 $0.136 \%$ 의 함량을 나타내어 대조구 $(0.103 \%)$ 와 비교하여 총 페놀 성 화합물 함량이 증가하였음을 알 수 있었다. 반면, 아로 니아 청을 첨가한 $\mathrm{MBA}$ 와인의 경우에는 $0.095 \%$ 의 함량을 나타내어 오히려 대조구보다 약간 감소하였다. 총 안토시 아닌 함량 분석 결과, 아로니아 생과를 첨가한 $\mathrm{MBA}$ 와인 에서 총 안토시아닌 함량이 $9,541 \mathrm{mg} / \mathrm{L}$ 로 측정되어 3.930 $4.381 \mathrm{mg} / \mathrm{L}$ 로 측정된 다른 시험구들보다 2 배 이상의 높은 함량을 나타내었다. 총 플라보노이드 함량 분석 결과, 아로 니아 생과와 아로니아 분말을 첨가한 $\mathrm{MBA}$ 와인에서 각각 $1,506 \mu \mathrm{M}$ 과 $1,638 \mu \mathrm{M}$ 로 측정되어 대조구 $(1016 \mu \mathrm{M})$ 보다 크게 증가하였음을 알 수 있었다. 아로니아 청을 첨가한 $\mathrm{MBA}$ 와인의 경우에는 총 페놀성 화합물 분석 결과와 마찬 가지로 대조구보다 낮은 $979 \mu \mathrm{M}$ 의 총 플라보노이드 함량 이 확인되었다. 상기 항산화 성분들은 베리류 등 과실에
다량 함유되어 강력한 항산화 작용을 한다고 알려져 있거 나, 레드와인의 적색도에 큰 영향을 미쳐 품질 평가의 주요 지표로 이용되는 중요한 성분들이다(Yook 등, 2007; Chang 등, 2008). 한국산 적포도주 색도에 관한 Lee 등(2002)의 연구에 따르면, 와인의 총 페놀함량과 intensity 값은 양의 상관관계를 나타내어 총 페놀함량이 높을수록 높은 intensity값을 나타낸다고 보고하였으며, 본 연구에서도 앞 서 intensity가 가장 높게 확인된 아로니아 생과를 첨가한 $\mathrm{MBA}$ 와인의 총 페놀성 화합물 함량이 가장 높게 나타났 다. 아로니아 청을 첨가한 $\mathrm{MBA}$ 와인의 경우에는 낮은 함량의 항산화 성분들이 확인되었는데, 이는 발효 초기 아로니아 청 첨가 와인의 낮은 intensity를 고려하였을 때, 파쇄되지 않은 과육에서 다양한 성분들이 원활히 용출되 지 않았음을 의미한다. 다른 시험구들의 경우에는 생과가 파쇄되어 첨가되거나, 분말 형태로 발효에 이용되었기 때 문에 발효 과정 중 발생되는 약 $20-25^{\circ} \mathrm{C}$ 의 높은 온도와 $12 \%$ 에 달하는 알코올에 의해 과육의 기능성 성분들이 충 분히 용출된 것으로 판단된다.

$\mathrm{DPPH}$ 라디칼은 항산화 성분의 전자공여능 작용으로 라디칼이 소거되어 보라색이 탈색되는 정도를 흡광도로 측정하는 원리로 항산화능을 측정하는 방법이다. $\mathrm{DPPH}$ 라디칼 소거능 측정 결과, 대조구 와인은 $58.49 \%$ 의 소거 활성을 나타내었으며, 아로니아 생과와 분말을 첨가한 $\mathrm{MBA}$ 와인들은 각각 $63.59 \%$ 와 $60.02 \%$ 로 대조구보다 높게 측정되었으며, 아로니아 청을 첨가한 $\mathrm{MBA}$ 와인은 대조구 보다 낮은 $56.63 \%$ 의 DPPH 라디칼 소거 활성을 나타내었 다. ABTS 라디칼 소거능은 potassium persulfate의 반응에 의해 생성되는 ABTS free radical이 항산화 물질에 의해 제거되면서 청록색이 탈색되는 원리를 이용한 측정 방법 이다(Joo 등, 2011). ABTS 라디칼 소거능 역시, 아로니아 생과와 아로니아 분말을 첨가한 $\mathrm{MBA}$ 와인들에서 각각 $0.564 \mathrm{mM}$ 과 $0.567 \mathrm{mM}$ 의 $\mathrm{ABTS}$ 라디칼 소거능이 확인되어 대조구 $(0.549 \mathrm{mM})$ 보다 높게 측정되었으며, 아로니아 청을 첨가한 $\mathrm{MBA}$ 와인은 $0.540 \mathrm{mM}$ 로 대조구보다 약간 낮게 측정되었다. FRAP 활성 역시 마찬가지로 아로니아 생과

Table 3. Sensory scores of MBA wines added with different types of the preprocessed aronia after alcohol fermentation

\begin{tabular}{cccccccc}
\hline Sample $^{1)}$ & Color & Flavor & Sweetness & Bitterness & Sourness & Body & Overall preference \\
\hline Control & $6.40 \pm 1.31^{2) a 3)}$ & $6.00 \pm 1.65^{\mathrm{a}}$ & $4.70 \pm 1.66^{\mathrm{a}}$ & $5.05 \pm 1.19^{\mathrm{a}}$ & $4.95 \pm 1.79^{\mathrm{a}}$ & $4.55 \pm 0.94^{\mathrm{a}}$ & $5.55 \pm 1.79^{\mathrm{a}}$ \\
A & $6.55 \pm 1.10^{\mathrm{a}}$ & $5.50 \pm 1.15^{\mathrm{a}}$ & $4.25 \pm 1.16^{\mathrm{a}}$ & $4.95 \pm 1.47^{\mathrm{a}}$ & $5.10 \pm 1.68^{\mathrm{a}}$ & $5.40 \pm 0.99^{\mathrm{a}}$ & $5.10 \pm 1.48^{\mathrm{a}}$ \\
B & $6.80 \pm 1.47^{\mathrm{a}}$ & $5.85 \pm 1.27^{\mathrm{a}}$ & $5.80 \pm 1.79^{\mathrm{a}}$ & $5.25 \pm 1.55^{\mathrm{a}}$ & $5.55 \pm 1.54^{\mathrm{a}}$ & $6.05 \pm 1.19^{\mathrm{a}}$ & $6.40 \pm 1.35^{\mathrm{a}}$ \\
C & $6.55 \pm 1.19^{\mathrm{a}}$ & $5.40 \pm 1.96^{\mathrm{a}}$ & $3.70 \pm 1.69^{\mathrm{a}}$ & $4.70 \pm 1.45^{\mathrm{a}}$ & $4.60 \pm 1.82^{\mathrm{a}}$ & $5.70 \pm 1.26^{\mathrm{a}}$ & $4.50 \pm 1.61^{\mathrm{a}}$ \\
\hline
\end{tabular}

${ }^{1)}$ Control, Muscat Bailey A (MBA); A, MBA+aronia fruit; B, MBA+aronia extract; C, MBA+aronia powder.

${ }^{2}$ All values are mean $\pm \mathrm{SD}(\mathrm{n}=3)$ and represented the mean of 20 observations using on hedonic scale of 1 (dislike very much) to 7 (like very much).

${ }^{3}$ Different letters within the same column indicate significant different $(p<0.05)$. 
와 분말을 첨가한 $\mathrm{MBA}$ 와인에서 대조구 $(2.08 \mathrm{mM})$ 보다 높은 $2.75 \mathrm{mM}$ 과 $2.49 \mathrm{mM}$ 의 활성을 나타내었으며, 아로니 아 청 첨가 $\mathrm{MBA}$ 와인은 $1.97 \mathrm{mM}$ 로 가장 낮은 활성을 나타내었다. 일부 항산화능의 차이는 항산화 물질마다 활 성 측정 시약과의 반응 정도에 의한 차이 또는 폴리페놀 화합물외의 식물에 포함된 다양한 생리활성물질의 함량 에 따라 차이가 발생된 것으로 판단된다.

Yoon 등(2017)은 아로니아와 캠벨얼리를 비율별로 혼합 하여 와인을 제조하였을 때, 아로니아의 함량이 증가할수 록 DPPH 라디칼 소거능이 증가되었다고 보고하였다. 본 연구에서도 총 페놀성 화합물, 총 안토시아닌, 총 플라보노 이드와 같은 항산화 성분의 함량이 높은 아로니아 생과 및 아로니아 분말 첨가 $\mathrm{MBA}$ 와인에서 $\mathrm{DPPH}, \mathrm{ABTS}, \mathrm{FRAP}$ 와 같은 항산화 활성이 우수하다고 확인되었으며, 전처리 공정 중 과육이 제거된 아로니아 청 첨가 $\mathrm{MBA}$ 와인의 경우에는 항산화 성분 및 활성 모두 대조구보다 낮게 측정 되어 $\mathrm{MBA}$ 와인의 기능성 향상을 위해서는 발효 과정 중 아로니아 과육을 반드시 첨가해야 할 것으로 판단된다.

\section{와인의 관능평가}

전처리 공정을 달리한 아로니아 첨가 $\mathrm{MBA}$ 와인의 관능 평가 결과는 Table 3 에 나타내었다. 와인의 색 항목에서는 모든 아로니아 첨가 $\mathrm{MBA}$ 와인들이 대조구보다 높은 점수 를 받았으며, 특히 아로니아 청 첨가 $\mathrm{MBA}$ 와인이 가장 높은 점수를 얻었다. 향미 항목에서는 모든 아로니아 첨가 MBA 와인들이 대조구보다 낮은 평가를 받았으며, 이는 아로니아가 캠벨얼리보다 향기성분의 함량이 적기 때문 으로 보여지며, 과육이 직접 첨가된 아로니아 생과 및 분말 첨가 $\mathrm{MBA}$ 와인의 경우에는 아로니아 청 첨가 $\mathrm{MBA}$ 와인 보다도 훨씬 낮은 향미 점수를 받았다. 맛 항목에서도 아로 니아 청 첨가 와인이 단맛, 쓴맛, 신맛에서 가장 높은 평가 를 받았으며, 분말 첨가 와인은 단맛과 쓴맛, 신맛에서 가장 낮은 평가를 받았다. 와인의 조직감에서도 아로니아 청 첨가 와인이 가장 높은 평가를 받았다. 아로니아 과육이 제거되어 첨가된 아로니아 청은 와인의 적절한 탄닌감과 조직감 향상에 기여한 것으로 판단되며, 분말 첨가 와인은 아로니아 건조 후 분쇄과정에서 과육의 표면적이 넓어져 아로니아의 떫은맛 성분들이 다량 용출되어 기호도가 떨 어진 것으로 판단된다. 종합적으로 평가한 기호도에서도 아로니아 청을 첨가한 와인이 아로니아를 첨가하지 않은 대조구 와인, 생과와 분말을 첨가하여 발효한 $\mathrm{MBA}$ 와인들 보다 높은 평가를 받았다.

\section{요 약}

본 연구는 국산 $\mathrm{MBA}$ 와인의 주질 개선 및 기능성 향상
을 위해 각종 폴리페놀 성분 등이 풍부하여 항산화능이 우수하다고 알려진 아로니아를 첨가한 $\mathrm{MBA}$ 와인을 제조 하였다. 아로니아의 경우, 신맛과 떫은맛이 강해 생과로 이용되기 어렵기 때문에 전처리 공정을 달리하여 3 가지 형태로 $\mathrm{MBA}$ 에 첨가한 후 발효를 진행하였다. 아로니아 첨가 형태에 따른 $\mathrm{MBA}$ 와인의 발효 특성을 분석한 결과, 아로니아를 첨가하였을 때, 대조구와 비교하여 총산의 함 량이 증가한 것을 확인하였으며, 아로니아 분말 첨가 $\mathrm{MBA}$ 와인의 $\mathrm{pH}$ 가 다른 와인들보다 높은 것을 확인하였다. 하지 만 모든 와인에서 정상적으로 $12 \%$ 이상의 알코올을 생성 하는 것을 보아 $\mathrm{MBA}$ 와인 제조시에 총 와인 무게 대비 $10 \%$ 이내의 아로니아는 어떠한 형태로 첨가되더라도 효 모의 생육 및 와인 발효에 큰 영향을 주지 않음을 알 수 있었다. 레드와인의 품질 지표인 색도의 경우, 모든 아로니 아 첨가 $\mathrm{MBA}$ 와인에서 대조구보다 높은 hue value를 확인 하였으며, 과육이 첨가된 아로니아 생과 및 분말 첨가 $\mathrm{MBA}$ 와인의 intensity value가 대조구보다 높음을 확인하 였다. 각 와인의 Hunter's color value 분석 결과, 아로니아 생과 첨가 $\mathrm{MBA}$ 와인의 $\mathrm{L}^{*}$ value와 $\mathrm{a}^{*}$ value가 가장 낮았으 며, $b^{*}$ value는 가장 높게 측정되었다. 아로니아 청 첨가 $\mathrm{MBA}$ 와인의 경우에는 $\mathrm{L}^{*}$ value가 가장 높았으며, 모든 아로니아 첨가구에서 $\mathrm{b}^{*}$ value가 대조구보다 높게 확인되 었다. 아로니아 첨가에 따른 $\mathrm{MBA}$ 와인의 기능성 향상 여부를 확인하기 위하여 항산화 성분 및 활성을 비교하였 을 때, 아로니아 청을 첨가한 $\mathrm{MBA}$ 와인은 모든 항산화 지표들이 대조구보다 낮게 확인되었지만, 아로니아 생과 및 분말을 첨가한 $\mathrm{MBA}$ 와인은 대부분의 항산화 성분 및 활성이 크게 증가함을 확인하였다. 이는 아로니아 청이 전처리 공정 중 과육이 제거되었기 때문으로 사료된다. 관능검사 결과, 아로니아를 첨가한 $\mathrm{MBA}$ 와인들은 색상에 서 좋은 평가를 받았지만, 아로니아 청 첨가 $\mathrm{MBA}$ 와인을 제외한 와인들은 대부분의 항목에서 대조구보다 낮은 평 가를 받았다. 종합적으로 보면 아로니아 청을 첨가한 $\mathrm{MBA}$ 와인의 경우에는 기능성은 약해지나 관능적 품질 및 기호 성이 향상됨을 알 수 있었고, 아로니아 생과와 분말을 첨가 한 $\mathrm{MBA}$ 와인의 경우에는 기능성은 크게 증가되나 아로니 아 특유의 떫은맛에 의해 관능적 품질이 저해되는 것을 확인할 수 있었다. 따라서 국산 $\mathrm{MBA}$ 와인의 주질 개선과 기능성 향상을 동시에 달성하기 위해서는 아로니아 청 전 처리 공정에서 아로니아의 기능성 성분들이 더욱 용출될 수 있는 추가적인 연구가 이루어져야 할 것으로 판단된다.

\section{감사의 글}

본 연구는 2019년 한국연구재단 과제(2017R1D1A3B0 3033451)의 연구비 지원에 의해 수행되었으며, 이에 감사 
드립니다.

\section{Conflict of interests}

The authors declare no potential conflict of interest.

\section{ORCID}

Kyu-Taek Choi https://orcid.org/0000-0002-2769-3308 Heui-Dong Park https://orcid.org/0000-0001-5042-036X

\section{References}

Ahmed H. Principles and Reactions of Protein Extraction, Purification and Characterization. CRC Press, London, England, p 350-352 (2004)

Amerine MA, Ough CS. Methods for Analysis of Musts and Wines. Wiley \& Sons, New York, USA, p 176-180 (1980)

AOAC. Official Method of Analysis 17th ed, Association of Official Analytical Chemists, Washington DC, USA, p 210-219 (2000)

Bang JS, Cho KS. A study on the history of the Korean wine industry. TMOR, 13, 111-122 (2001)

Benzie IFF, Strain JJ. The ferric reducing ability of plasma (FRAP) as a measure of "antioxidant power": The FRAP assay. Anal Biochem, 239, 70-76 (1996)

Blois MS. Antioxidant determinations by the use of a stable free radical. Nature, 181, 1188-1200 (1958)

Chang EH, Jeong ST, Park KS, Yun HK, Roh JH, Jang HI, Choi JU. Characteristics of domestic and imported red wines. Korean J Food Preserv, 15, 203-208 (2008)

Choi SH, Hong YA, Choi YJ, Park HD. Identification and characterization of wild yeasts isolated from Korean domestic grape varieties. Korean J Food Preserv, 18, 604-611 (2011)

Han SZ. Protective efficacies of aronia melanocarpa (blackberry) on the allyl alcohol-damaged hepatocyte of mice. Korean J Pharmacogn, 44, 91-96 (2013)

Hong JH, Ko JY. The application development of geographical indication system for Korean wine region. JFM, 18, 131-152 (2015)

Hou DX. Potential mechanisms of cancer chemoprevention by anthocyanins. Curr Mol Med, 3, 149-159 (2003)

Hwang SW, Park HD. Properties of red wine fermented using freeze-concentrated Muscat Bailey A grape juice. Korean J Food Preserv, 17, 807-813 (2010)
Jakobek L, Drenjancevic M, Jukic V, Seruga M. Phenolic acids, flavonols, anthocyanins and antiradical activity of "Nero", "Viking", "Galicianka" and wild chokeberries. Sci Hortic, 147, 56-63 (2012)

Jeong HS, Lee SB, Yeo SB, Kim DH, Choi JS, Kim DH, Yeo SH, Park HD. Blending effect of Campbell Early and aronia wines fermented by the mixed culture of Pichia anomala JK04 and Saccharomyces cerevisiae Fermivin. Korean J Food Preserv, 24, 472-482 (2017)

Jeong ST. The Status of Domestic Wine Industry and the Strategy for the Competitiveness Improvement. Research Data Report of KREI, D376-1 (2014)

Joo OS, Kang ST, Jeong CH, Lim JW, Park YG, Cho KM. Manufacturing of the enhances antioxidative wine using using a ripe Daebong persimmon (Dispyros kaki L.). J Appl Biol Chem, 54, 126-134 (2011)

Kim DH, Kim JH, Chun SS. Quality and antioxidant activity of custard cream premix with Aronia melanocarpa. J Korean Soc Food Sci Nutr, 47, 786-794 (2018)

Kim EK, Kim IY, Ko JY, Yim SB, Jeong YH. Physicochemical characteristics and acceptability of commercial low-priced French wines. J Korean Soc Food Sci Nutr, 39, 1666-1671 (2010)

Kim JI, Lee NK, Hahm YT. Isolation and identification of wild yeast and its use for the production of grapewine. Korean J Microbiol, 43, 217-221 (2007)

Kim JS, Sim JY, Yook C. Development of red wine using domestic grapes, Campbell Early. Part (I) - Characteristics of red wine fermentation using Campbell Early and different sugars. Korean J Food Sci Technol, 33, 319-326 (2001)

Kim MS, Yeo SH, Park HD. Fermentation characteristics of Campbell Early wine by indigenous Saccharomyces cerevisiae yeasts with resistance to potassium metabisulfite and high sugar concentration. Korean J Food Preserv, 20, 744-750 (2013)

Ko JS. Brewing Engineering. Yu Han Publishing Co, Seoul, Korea, p 1-393 (2008)

Ministry of Food and Drug Safety. Korea Food Code. Ministry of Food and Drug Safety, Osong, Korea, p 3-25 (2018)

Lee JC, Choi YK, Yoon JY, Kim HJ, Yi DH, Jung ST, Lee WJ. Influence of Oenococcus oeni inoculation time on the quality of MBA wine. Culi Sci \& Hos Res, 21, 229-241 (2015)

Lee JE, Shin YS, Sim JK, Kim SS, Koh KH. Study on the color characteristics of Korean red. Korean J Food Sci 
Technol, 34, 164-169 (2002)

Lee JH, Park JH, Jeong JS, Song DN, Kim YH, Eom HJ. Quality characteristics of sweet persimmon jams added with aronia juice. Korean J Food Nutr, 30, 433-439 (2017)

Lee JK, Kim JS. Study on the deacidification of wine made from Campbell Early. Korean J Food Sci Technol, 38, 408-413 (2006)

Lee JM, Durst RW, Wrolstad RE. Determination of total monomeric anthocyanin pigment content of fruit juices, beverages, natural colorants, and wines by the $\mathrm{pH}$ differential method: Collaborative study. J AOAC Int, 88, 1269-1278 (2005)

Lee SJ, Lee JE, Kim SS. Development of Korean red wines using various grape varieties and preference measurement. Korean J Food Sci Technol, 36, 911-918 (2004)

Moon YJ, Lee MS, Sung CK. The fermentation properties of red wine using active dry yeast strains. J Korean Soc Food Sci Nutr, 17, 450-457 (2004)

Ortiz J, Marín-Arroyo MR, Noriega-Domínguez MJ, Navarro M, Arozarena I. Color, phenolics, and antioxidant activity of blackberry (Rubus glaucus Benth.), blueberry (Vaccinium floribundum Kunth.), and apple wines from Ecuador. J Food Sci, 78, 985-993 (2013)

Park HJ, Chung HJ. Influence of the addition of aronia powder on the quality and antioxidant activity of muffins. Korean J Food Preserv, 21, 668-675 (2014)

Park SM, Heo JY, Kang JW. Preliminary study for the industrialization of ice wine. Research Report of RIG, RIG D16-10 (2016)

Park WM, Park HG, Rhee SJ, Lee CH, Yoon KE. Suitability of domestic grape, cultivar Campbell's Early, for production of red wine. Korean J Food Sci Technol, 34, 590-596 (2002)

Roh HI, Chang EH, Joeng ST, Jahng KY. Characteristics of fermentation and wine quality. Korean J Food Preserv, 15, 317-324 (2008)

Shin DH, Choe TB. Study on the bioactive characteristics of Aronia extract as a cosmeatic raw material. Kor J Aesthet Cosmetol, 13, 275-283 (2015)

Song JH. Quality characteristics of yogurt dressing containing aronia (black chokeberry). MS Thesis, Sejong University, Korea, p 1-3 (2016)

Stintzing FC, Stintzing AS, Carle R, Frei B, Wrolstad RE. Color and antioxidant properties of cyanidin-based anthocyanin pigments. J Agric Food Chem, 50, 6172-6181 (2002)

Stratil P, Kuban V, Fojtova J. Comparison of the phenolic content and total antioxidant activity in wines as determined by spectrophotometric methods. Czech J Food Sci, 26, 242-253 (2008)

Yook C, Seo MH, Kim DH, Kim JS. Quality improvement of Campbell Early wine by mixing with different fruits. Korean J Food Sci Technol, 39, 390-399 (2007)

Yoon HS, Park HJ, Park JH, Jeon JO, Jeong CW, Choi WI, Kim SD, Park JM. Quality characteristics and volatile flavor components of aronia wine. J. Korean Soc Food Sci Nutr, 30, 599-608 (2017)

Zhishen J, Mengcheng T, Jianming W. The determination of flavonoid contents in mulberry and their scavenging effects on superoxide radicals. Food Chem, 64, 555-559 (1999) 